\title{
The impact of retail shoes sales promotional activities on ladies' purchase intentions
}

\author{
Sameen Akhter \\ Research Scholar, Department of Management Sciences \\ The Islamia University of Bahawalpur, Pakistan \\ E-mail: sameenakhter@hotmail.com \\ Muhammad Rizwan \\ Lecturer, Department of Management Sciences \\ The IslamiaUniversity of Bahawalpur, Pakistan \\ E-mail: rizwan.arshad@iub.edu.pk
}

Shufa Shujaat

Research Scholar, Department of Management Sciences

The Islamia University of Bahawalpur, Pakistan

E-mail: shufa.shujaat@hotmail.com

\section{Zarmina Durrani}

Research Scholar, Department of Management Sciences

The Islamia University of Bahawalpur, Pakistan

E-mail: zarmeena.durrani@gmail.com

Accepted: June 19, 2014

Doi:10.5296/ jpag.v4i2.5843 URL: http://dx.doi.org/10.5296/ jpag.v4i2.5843

\begin{abstract}
In this study we examine how different variables impact sales promotions that ultimately influence purchase intentions of customer. The main purpose of this study is to examine how
\end{abstract}


attitude towards discount affects sales promotional activities to influence customers' purchase intention along with the impact of customer loyalty and in store displays on them. To collect information, the survey method was conducted through questionnaires to take response from the customers of Stylo shoes in Bahawalpur. For this purpose, a sample of 164 customers was selected through the simple random sampling technique and then the data was entered in SPSS software for descriptive and inferential statistical analysis. The results of the study indicate that there is no relationship between customer loyalty and sales promotion whereas attitude towards discount has a positive relation with sales promotion. Likewise, sales promotion, customer loyalty and in-store display has a significant relationshipwith purchase intention. The results of this study will assist retailers to select thebest promotional tool that will influence purchase intentions of customer. These plans help businessmen andmarketers to gain competitive advantage over their competitors and enable the businesses to earn maximum profit.

Keywords: Sales promotion, attitude towards discount, purchase intention, customer loyalty, in store display, Stylo shoes

\section{Introduction}

In this world of keen competition, sellers use various tools and strategies to attract customers and increase their profitability. Sales promotion is one of the best tools to attract the attention of new customers and retain the old ones. This tool helps in building customers' loyalty in brand which results in increase in sales. Nowadays different marketing strategies are being implemented by the marketers to survive in the current situation of tough competition by using different marketing tools such as, advertising, publicity, promotions etc.

Marketing mix consists of seven aspects. Sales promotion is one of them. Others include publicity or public relations, advertising, corporate image, direct marketing, personal selling and exhibitions.Marketing strategies involve such communication tools that work for a limited time to increase customer and market demand for a product with improved product availability in market through media and non-media sources. Such offers include prizes, coupons, free samples, rebates, discounts, premiums, point of purchase displays etc.

Sales promotion assist consumers to evaluate brands and increase purchase possibilities by offering benefits to them and make them think to buy that product about which they might not have thought of. Therefore, it is helpful for retailers to use these tactics to increase customer visits and sales by considering customers' preferences.

Retailers differentiate their shops through image communication and various promotional offerings that stimulate customers to visit and purchase merchandise. Sales promotions in the form of price discounts, "buy one get one free" and free samples have become a popular tool for not only fulfilling the purpose of attracting customers and increased sales, but it also moves surplus stock out and creates a space for new seasonal goods. In this world of progressive competition, these tools have become an essential part of businesses to cope with the situation of over-capacity and reduced customer rate. Such sales occur at different times 
of year especially at the time of any event such as opening sales, New Year sales, anniversary sales, end of season sales etc.

Sales promotions are beneficial for sellers in several ways such as; it assists in stimulating customers' unplanned purchases along with the impact of different variables such as in-store display, attitude towards discount and customer loyalty on them. They motivate customers to cut the stockpile that consequently reduces inventory costs and attract customers to increase store visits. Store visits can lead to trigger unplanned purchases when promotions are offered and customer considers it a valuable exchange. When the offered discount matches or exceeds the customers' expectations then they consider that product a valuable exchange of money with increased benefits and reduced costs (Rizwan et al., 2013).

In addition to the promotional activities that are being carried out by many departmental stores, they also provide some types of services to facilitate the customer to reach his satisfaction level. These services include free parking, membership cards, free home delivery etc. within a competitive structure. It is not every customer purchase which leads to customer loyalty; profitability can only be increased by facilitating him up to the maximum level to attain his satisfaction that is considered an ultimate source of building loyalty. Customers with repeat purchases constitutes a major portion of profit to the organization as the cost of retaining old customers is less than attracting the new ones.

\section{Literature Review}

\subsection{Sales promotions}

A collection of short term incentive tools that are referred to as a key ingredient in marketing campaigns to stimulate purchases by the customers is called sales promotion (Kotler, 2003).

One of the methods used by many firms to communicate with intended target market is sales promotion. It comprises of those promotional activities that creates and stimulates a sense of purchase (trial) and interest in a product by the customers (BagavathiPillai, 2007).It excludes personal selling, advertising and publicity. It is distinctive in that it offers an extra incentive for the action (Adrian Palmer, 2004).

In this study we examine how different variables impact sales promotions that ultimately influence purchase intentions of customer. These variables involve customers' attitude towards discount along with the impact of customer loyalty and in store display on purchase intentions. Sales promotions can be in two forms i.e. monetary and non-monetary ones, providing both, hedonic and utilitarian assistances to the customers. Intrinsic stimulation, self-esteem, exploration, value expression and entertainment are the key elements of hedonic benefits (Chandon, Wansink and Laurent. 2000), whereas quality of product, convenience in shopping, saving in time, efforts and costs are considered as utilitarian benefits (Luk and Yip, 2008). Sales promotions are carried out in many countries seasonally or annually. These activities might involve unique displays of physical surroundings with the aid of music, interior décor and price discounts of various ranges. These sales provide product appeal with reduced prices ( $\mathrm{A}^{\prime}$ lvarez and Casielles, 2005; Rizwan et al., 2013) and it is considered as a core objective of "sales" resulting in attracting crowds to the malls. General sales, Christmas 
sales and change of season sales; these three types of sales were studied by Fam (2003), according to which, sales promotion reduces inventory costs by stock clearance along with the further benefits of increased profitability,attracting new customers, reinforcement of store image and generating more in-store excitement.

\subsection{Attitude towards discount}

The attitude of a person towards an offered price that is particularly cheap or lower than the normal price is called attitude towards discount.Past researches showed that price presentations and promotional messages framing influences customers' purchase intentions and their price perceptions about a particular product (Das, 1992; Sinha et al., 1999; Sinha and Smith, 2000). In an economical context, consumers seem doubtful towards retailers' pricing and promotional strategies supposed to reduce their everyday expenditure. Specifically,customers have learnt to question advertised discounts and reference prices, as well as the quantity discount heuristic (Binkley \& Bejnarowicz, 2003). This study examines how purchase intentions are influenced by the interaction of promotional characteristics and customers' attitude towards price discounts.According to Taylor (1998), environmental context, motives and goals are the basis of selection when customers are provided with diverse information processing strategies.Customers are also provided with monetary savings in price promotion strategies.

\section{H1: Customers having positive attitude towards discount respond positively to sales promotion.}

\subsection{Customer loyalty}

Loyalty is faithfulness or devotion to a person, group, cause or a country. It is not every customer purchase that leads him towards customer loyalty. If customer loyalty and customer satisfaction upto maximum possible level is focused then it positively adds to profitability of the firms Heskett et al. (1994).For defining and measuring loyalty, many researches therefore, have been carried out in past by different researchers (Newman, 1973; Tellis, 1988; Selnes, 1993; Jones and Sasser, 1995; Griffin, 1996; Oliver, 1997; Bowen and Shoemaker, 1998; Bowen and Chen, 2001; Lee and Cunningham, 2001; Fullerton, 2005; Rizwan et al., 2013). Based on loyalty, customers are generally categorized into loyal and non-loyal customers. Non-loyal customers are attracted towards gains only. Contrary to this, loyal customers respond with no difference towards gains and losses both (Krishnamurthi et al., 1992).

Sales promotionoffer and provide benefits to the customersto seek their attention and to motivate them to purchase, therefore it is considered an important tool in building customer loyalty. It has been determined that the cost of gaining new customers is considerably higher than that of retaining the old ones (Fornell and Wernerfelt, 1987). Customer loyalty is a key of increasing customer retention rates and hence profitability of the organization (Reichheld, 1996). In this progressive competitive environment, customer loyalty is considered a main issue in many journals for the survival of businesses.

For getting a control over marketing mix and protection from competition, sales promotion provide sellers to attract profitable customers which may assist in building brand loyalty 
(Shira 2003). As it has been already developed that the cost of retaining old customer is cheaper than getting a new one (Rust and Zahorik, 1993), loyalty is eagerly being required by all retailers. Therefore, retailers are trying harder to cope with the changing competitive environment by using different promotional tools and understanding the preferences of customers. Customers' preferences and commitment for a brand or a product play a vital role in building customer loyalty as it has been proved earlier by Nagar (2009), that only repeat purchasers are profitable. Customer's commitment adds to the profitability of the businesses but it is not every purchase that leads towards customer loyalty and profitability. Sales promotions enable customers to get motivated towards unplanned purchases by considering it a valuable exchange.

\section{H2: Loyal customers respond positively to sales promotion.}

\section{H3: Customer loyalty positively influences purchase intentions.}

\subsection{Sales promotion and purchase intentions (PI)}

Purchase intention (PI) refers to the interaction of perceptions, attitudes and needs of a customer for a particular product and its respective company that influences the likelihood of buying that product. PI is influenced by interest-creating actions; usually these are temporary marketing events other than publicity, straight advertising and individual advertising. The aim of purchase intention is to inspire, excite and demands the buy and most wanted behavioral response of the consumers. Purchase intention describes promotional techniques using special short-term tools to motivate customers of a target market to undertake or respond certain activity (draypin.inc).Many researches have been conducted by different authors in Western countries such as Canada (d'Astous and Jacob, 2002), New Zealand (Parson, 2003), Australia (Kwok and Uncles, 2005; Dawes, 2004), UK (Gilbert and Jackaria, 2002), but little is known by the retailers of Asian countries aboutthe connection between sales promotions and their impact on customers' purchase intentions.

If consumers are in a market having pre planned purchase goals then they are more likely to be attracted by the promotions and discounts offered by that particular product. Therefore, their purchase likelihood would be higher. Customers' perception about a product is influenced by the promotional framing i.e. how the promotional message is communicated, according to price presentation research. Different promotional techniques impact purchase intentions of customersat any point of time i.e. current as well as future (DelVecchio et al., 2006).

\section{H4: Sales promotion has a positive impact on consumers purchase intentions.}

\subsection{In store display and purchase intention}

Shopping malls nowadays, focus on the development of impressive and attractive physical surrounding to attract customers to visit the shops that are being housed in them. A shopping mall consists of various types of shops within a single roof offering and delivering value to customers. Customers are attracted by the in store display and physical surrounding that influences customer to make a purchase as his perception about a product becomes relative to 
the display and it stimulates store patronizing in customers (Sit et al., 2003). One of the main causes of store patronizing is pleasant external atmosphere ( Jin and Kim, 2003). This image attraction which consists of elements like décor, music, lighting, interior architecture, furniture, cleanliness and display (Baker, 1987) is advantageous and profitable for the retailers. All these environmental factors influence customers' perceptions about the quality of product (Baker, 1987) and depending on the functional needs of customers, they arouse attraction in them( ElSayed et al., 2003) which shows a positive connection between the external environment and customers (Kim, 2002; Keng et al., 2007). This environmental stimuli influence purchase intentions of customers by creating positive attitudes in them (Bitner, 1992). After experiencing such environment, customers may evaluate the product on the basis of its display and this may be a decisive point for them to make a repeat purchase so, we hypothesized as:

\section{H5: In store display has a positive impact on consumers purchase intentions.}

\section{Research Methodology}

This study is descriptive in its nature. Descriptive research can be illustrated as describing something, some phenomenon or any particular situation. Descriptive researches are those researches that describe the current situation instead of inferring, interpreting and making judgments (Creswell, 1994). The core objective of descriptive research is verification of the developed hypotheses that reflect the existing situation. This type of study provides information about the current scenario and focus on past or present e.g. quality of life in a community or consumers' attitude towards any marketing activity (Kumar, 2005).

\subsection{Sample/Data}

The population for the current research is Stylo shoes customers in Bahawalpur. For gathering information, a survey was conducted through questionnaires with the sample of 200 female customers of Stylo shoes in Bahawalpur. The respondents were majorly 15 years or older and they had to have some know how about the promotions offered in Stylo shoes to attempt and complete the survey. Two main clusters were targeted to collect the sample data i.e. working professionals and students. The selection of working professionals and students is based on the results of the previous studies on sales promotion.

The current research utilizes a non-probability sampling technique that is convenience sampling. Convenience sampling is a sampling technique that obtains and collects the relevant information from the unit of study or sample that are easily available (Zikmund, 1997). Convenience sampling is generally used for collecting a large number of completed surveys efficiently, speedily and with economy (Lymet al., 2010).

\subsection{Procedures}

The questionnaire was distributed among 200 female respondents in Bahawalpur. These respondents were selected based on the criteria above mentioned. Before giving the questionnaire, the purpose of study and questions were explained to the respondents so that 
they can easily fill the questionnaire with relevant responses. A total of 164 questionnaires were selected as valid and rest of the questionnaires was not included in the further analysis due to incomplete or invalid responses. After collecting the completed questionnaires, the data of the questionnaires were coded and entered into SPSS sheet for further analysis.

\subsection{Reliability analysis}

All the variables of the given questionnaire are reliable as Cronbach's alpha values are more than acceptable compared with the recommended value of 0.50 by Nunnally (1970) and 0.60 by Moss et al. (1998). This shows that all the 27 items were reliable and valid to measure the opinions of consumers towards sales promotion.

Table 1: Reliability of Measurements Instrument

\begin{tabular}{|l|l|l|}
\hline Scales & Items & Cronbach's Alpha \\
\hline Attitude Towards Discounts & 8 & 0.744 \\
\hline Sales Promotion & 2 & 0.706 \\
\hline Customer Loyalty & 8 & 0.893 \\
\hline In Store Display & 5 & 0.636 \\
\hline Purchase Intention & 4 & 0.870 \\
\hline
\end{tabular}

\section{Hypothesis Testing}

\subsection{Hypothesis Testing}

\subsubsection{Attitude towards price discount, customer loyalty and sales promotion}

According to the results of the study, attitude towards discount has a significant positive relationship with sales promotion with $(\beta=0.577)$ and $(p=0.000)$ while customer loyalty hasinsignificant relationship with sales promotion with $(\beta=-0.006)$ and $(p>0.05)$, which means attitude towards discount contribute more than $50 \%$ to sales promotion. Results of the current study validate $\mathrm{H} 1$ and rejects $\mathrm{H} 2$.

\subsubsection{Customer Loyalty, Sales Promotion, In-Store Display and Purchase Intention}

The regression results of the study confirm that customer loyalty, sales promotion and in-store display has significant positive relationship with purchase intention. Specifically, customer loyalty with $(\beta=0.806)$ and $(p=0.000)$, sales promotionwith $(\beta=0.091)$ and $(p=0.036)$ and In-store displaywith $(\beta=0.009)$ and $(\mathrm{p}=0.008)$. All these variables are in a positive relationship with the dependent variable i.e. purchase intention. The results show that the customer loyalty contributes more than $80 \%$ to purchase intention. Results of the current 
study validate $\mathrm{H} 3, \mathrm{H} 4$ and $\mathrm{H} 5$.

Table 2: Regression Results

\begin{tabular}{|c|c|c|c|c|}
\hline Hypothesis & Model Variables & Estimate & $\mathbf{P}$ & Results \\
\hline $\begin{array}{l}\mathrm{H} 1 \\
\mathrm{H} 2\end{array}$ & $\begin{array}{l}\text { ATD } \\
\text { Sales Promotion } \\
\mathrm{CL} \longrightarrow \\
\text { Sales Promotion }\end{array}$ & $\begin{array}{l}0.577 \\
-0.006\end{array}$ & $\begin{array}{l}0.000 \\
0.934\end{array}$ & $\begin{array}{l}\text { Supported } \\
\text { Not supported }\end{array}$ \\
\hline $\begin{array}{l}\text { H3 } \\
\text { H4 } \\
\text { H5 }\end{array}$ & $\begin{array}{l}\mathrm{CL} \\
\text { Purchase intention } \\
\mathrm{SP} \longrightarrow \text { Purthase intention } \\
\text { ISD } \longrightarrow \\
\text { Purchase intention }\end{array}$ & $\begin{array}{l}0.806 \\
0.091 \\
0.009\end{array}$ & $\begin{array}{l}0.000 \\
0.036 \\
0.008\end{array}$ & $\begin{array}{l}\text { Supported } \\
\text { Supported } \\
\text { Supported }\end{array}$ \\
\hline
\end{tabular}

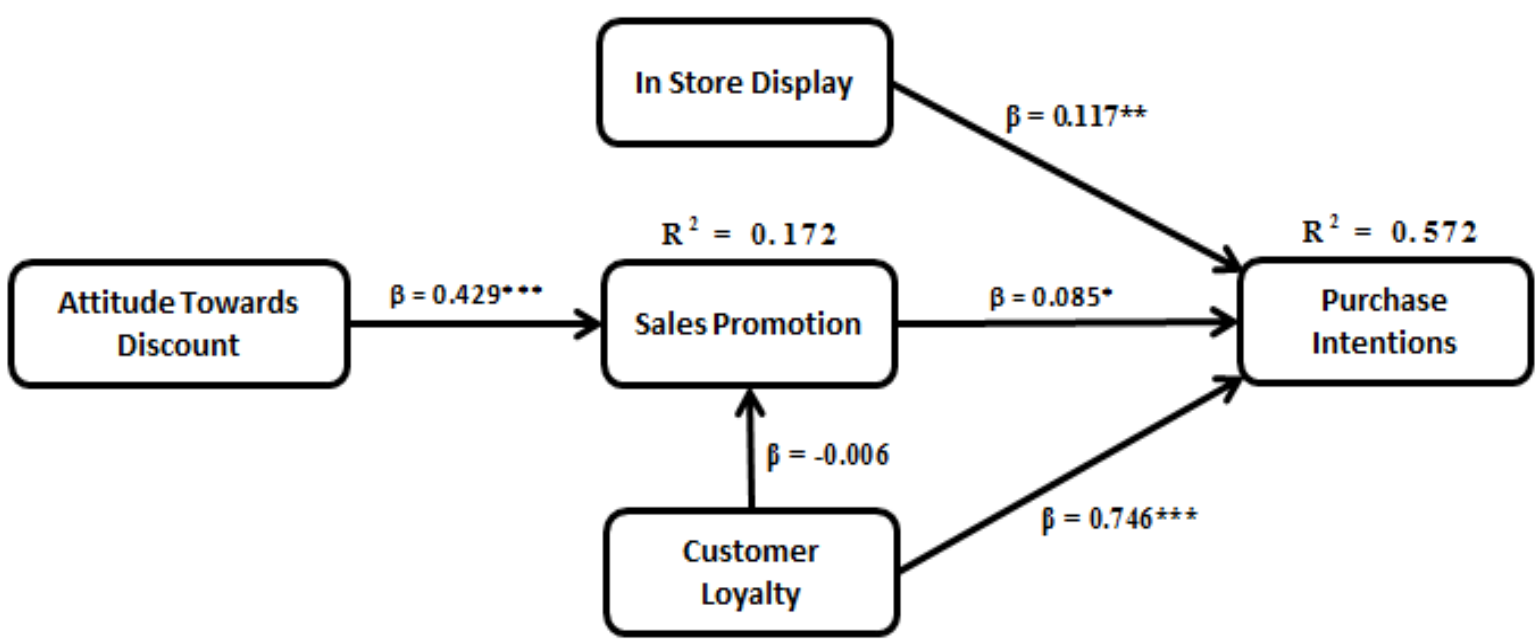

\section{Figure 1: Structural Model Results}

\section{Discussion}

This research studied how ladies respond to sales promotion in Stylo shoes. In-store display is one of the important predictors for sales promotion. In this research, customers were asked about shop preferences including bright lightings, interior and exterior decor, scented environment and selective soothing music to make the occasion memorable. These customers preferred shopping in large retail shoes store with music being played in the shop. We can find in past studies that music have significant impact on purchase intentions and mood of the audience (Keng et al., 2007; Alpert and Alpert, 2006; Baker, 1987). In this study it was found 
that spacious, neat and clean atmosphere of shop affect utilitarian shoppers' level of intention to patronize, money spent and time ( Jin and Kim, 2003).

Retail shops are generally taken on lease from the shop owners and the rental costs are based on the space occupied. Big spacious shops are only leased when their businesses are feasible for large space and for covering rental costs. One of the methods to make the shop look spacious is to elevate the interior as, according to the interior designer, by hanging wall mirrors we can not only elevate space, make shop look decorative but also provide the functional features to the shop (Smythe, 2011).

The result of this research also gave some important information about impact of promotion tools on consumer buying behavior. With respect to customer proneness to sale promotion, this study found that price discount and in-store display played a significant role in developing consumer-buying behavior. The results of this study confirmed that findings of previous study by, Blackwell, Miniard and Engel (2001) that price discounts play significant roles in influencing consumers' purchase trial behavior, and Smith and Sinha (2000), price promotions can induce consumers' buying behavior and result in a short term increase in sales.

The results of this study show that there is a positively significant relationship between sales promotion and purchase intention, because when the respondents were asked about the impact of sales promotion on their purchase intention, most of the respondents replied that promotional activities motivates them to make purchases. They often make purchase when they see promotional activities even they had no prior intentions of buying.

When respondents were asked about the relationship between customer loyalty and purchase intention, we found a positive significant relationship between them. Most of the respondents who were loyal to their brands told that their loyalty towards brand enforces them to make purchases. If the same product is available on some other store they would not buy it in fact they would wait, visit their brand and would make purchase from the brand they are loyal to.

This study shows that the customers who have positive attitude towards discount respond positively to sales promotion. Because some customers who have negative attitude towards discount believe that discounted products are of low quality hence they respond negatively to sales promotional activities but the consumers who have positive attitude towards discount does not believe in that low quality perspective instead they take discount and other sales promotional activities as blessing that when they cannot buy a product at original price then due to price discount or other sales promotional activities they can afford buying that product.

The study shows that there is an insignificant relationship between customer loyalty and sales promotion.

\section{Limitations And Future Research}

Upcoming researchers have more opportunities to do their research in improved situation and at various physical localities. This research has been conducted on Stylo Shoes only in Bahawalpur, Pakistan. Diverse environment always play a positive role that helps to affect 
respondent's behavior especially at place of work, shopping complexes or malls and supermarkets. Since this study was conducted majorly among university students and in different areas of Bahawalpur, it could not represent people of other rural and urban areas leading a totally different lifestyle. Finally, it is recommended for the future researchers to include interview and experimental method in doing study specifically at the place where business transactions are happening. It will assist scholars to attain more accurate information established on the respondents' fresh memory.

\section{References}

Adrian Palmer (2004). Introduction to Marketing Theory and Practice.2nd Edition, United State: Oxford University Press Inc.

A 'lvarez, B.A' .andCasielles, R.V. (2005), "Consumer evaluations of sales promotion: the effect on brand choice", European Journal of Marketing, Vol. 39 Nos 1/2, pp. 54-70.

BagavathiPillai R. S. N. (2007). Modern Marketing.Revised Edition. New Delhi: S. C hand and company Ltd.

Bagozzi, R.P. and Dholakia, U. (1999), "Goal setting and goal striving in consumer behavior", Journal of Marketing, Vol. 63, pp. 19-32 (special issue).

Baker, J. (1987), "The role of environment in marketing service: the consumer perspective", in Czepeil, J.A., Congram, C.A. and Shanahan, J. (Eds), The Service Challenge: Integrating for Competitive Advantage, American Marketing Association, Chicago, IL, pp. 79-84.

Bargh, J.A. (2002), "Losing consciousness: automatic influences on consumer judgment, behavior, and motivation”, Journal of Consumer Research, Vol. 29, pp. 280-5.

Bitner, M.J. (1992), "Servicescapes: the impact of physical surroundings on customers and employees", Journal of Marketing, Vol. 56 No. 2, pp. 57-71.

Bowen, J., \& Shoemaker S. (1998).Loyalty: A strategic commitment. The Cornell Hotel and Restaurant, Administration Quarterly February, 12-25.

Bowen. J. T.,\& Chen. S. L. (2001). The relationship between customer loyalty and customer satisfaction.International Journal of Contemporary Hospitality Management, 13(5), 213-217.

Chandon, P., Wansink, B. \& Laurent, G. (2000).A benefit congruency framework of sales promotion effectiveness.Journal of Marketing, 64 (4), 65-81.

Das, P.R. (1992), "Semantic cues and buyer evaluation of promotional communication", in Leone, R.P. and Kumar, V. (Eds), Enhancing Knowledge Development in Marketing, American Marketing Association, Chicago, IL, pp. 12-17.

d'Astous, A. and Jacob, Z.I. (2002), "Understanding consumer reactions to premium-based promotional offers”, European Journal of Marketing, Vol. 36 Nos 11/12, pp. 1270-86.

DelVecchio, D., Henard, D.H. and Freling, T.H. (2006), "The effects of sales promotion on post-promotion brand preference: a meta-analysis", Journal of Retailing, Vol. 82 No. 3,pp. 
$203-13$.

El Sayed, I.M., Farrag, D.A. and Belk, R.W. (2003), "The effects of physical surroundings on Egyptian consumers' emotional states and buying intentions", Journal of International Consumer Marketing, Vol. 16 No. 1, pp. 5-27.

Fam, K.S. (2003), "Measuring an effective promotion campaign: lessons from retail advertisers in New Zealand, Portugal and Hungry", Marketing Intelligence \& Planning, Vol. 21 No. 5, pp. 282-91.

Fornell, C., \&Wernerfelt, B. (1987).Defensive marketing strategy by customer complaint management: A theoretical Analysis.Journal of Marketing Research, 24(4), 337-346.

Fullerton, G. (2005). How commitment both enables \& undermines marketing relationships. European Journal of Marketing, 39(11/12), 1372-1388.

Gilbert, D.C. and Jackaria, N. (2002), "The efficacy of sales promotions in UK supermarkets: a consumer view", International Journal of Retail \& Distribution Management, Vol. 30 No. 6, pp. 315-22.

Griffin, J. (1996). The internet's expanding role in building customer loyally. Direct Marketing, 59(7), 50-53.

Heskett, J. L., Jones, T. O., Loveman, G. W., Sasser, W.E., \& Schlesinger, L.A. (1994).Putting the service-profit chain to word.Harvard Business Review, 164-174.

Howard, D.J. and Kerin, R. (2006), "Broadening the scope of reference price advertising research: a field study of consumer shopping involvement", Journal of Marketing, Vol. 70, pp. 185-204.

Jin, B. and Kim, J.-O. (2003), "A typology of Korean discount shoppers: shopping motives, store attributes, and outcomes", International Journal of Service Industry Management, Vol. 14 No. 4, pp. 396-419.

Jones, T. O., \&Sasser, W. E. (1995).Why satisfied customers defect.Harvard Business Review, 73(6), 88-99.

Keng, C.-J., Huang, T.-L., Zheng, L.-J.and Hsu, M.K. (2007), "Modelling service encounters and customer experiential value in retailing”, International Journal of Service Industry Management, Vol. 18 No. 8, pp. 349-67.

Kim, Y.-K. (2002), "Consumer value: an application to mall and internet shopping”, International Journal of Retail \& Distribution Management, Vol. 30 No. 12, pp. 595-602.

kotler (2003),'Effect of Sales Promotion as a Tool on Organizational Performance", Journal of Emerging Trends in Economics and Management Sciences (JETEMS) 2 (1): 9-13

Krishnamurthi, L., Mazumdar, T. and Raj, S.P. (1992), "Asymetric response to price in consumer brand choice and purchase quantity decisions", Journal of Consumer Research, Vol. 19, pp. 387-400. 
Kwok, S. and Uncles, M. (2005), "Sales promotion effectiveness: the impact of consumer differences at an ethnicity-group level”, Journal of Product \& Brand Management, Vol. 14No. 3, pp. $170-86$.

Lawson, R. (1997), “Consumer decision making within a goal-driven framework",Psychology\& Marketing, Vol. 14 No. 5, pp. 427-49.

Lee, M., \& Cunningham, L. F. (2001).A cost-benefit approach to understanding service loyalty.Journal of Services Marketing, 15(2), 113-130

Luk, S. T. K. \& Yip, L. S. C. (2008).The moderator effect of monetary sales promotion on relationship between brand trust and purchase behavior.Brand Management, 15 (6), 452-464.

Nagar, K. (2009). Evaluating the effects of consumer sales on brand loyal and brand switching segments.VISSION-Journal of Business Perspective, 13 (4), 35-48.

Newman, J. W., \&Werbel, R. A. (1973).Multivariate analysis of brand loyalty for major household appliances.Journal of Marketing Research, 10(4), 404-409.

Parson, G.A. (2003), "Assessing the effectiveness of shopping mall promotions: customer analysis",International Journal of Retail \& Distribution Management, Vol. 31 No. 2, pp. 74-9.

Peterman, M.L. (1997), "The effects of concrete and abstract consumer goals on information processing", Psychology \& Marketing, Vol. 14 No. 6, pp. 561-84.

Reichheld, F. F. (1996\$.The loyalty effect: The hidden force behind growth, profits, and lasting value. Boston, MA: Harvard Business School Press

Rizwan, M., Javed, M. A., Khan, M. T., Aslam, M. T., Anwar, K., Noor, S. \& Kanwal, W., (2013) The Impact of Promotional Tools on Consumer Buying Behavior: A study from Pakistan, Asian Journal of Empirical Research, 3(2), 114-130

Rizwan, M., Mahar, M. A., Shoukat, N., Javid, R. Z., Khan, G., Bhatti, M. D. \& Khichi, M. M. (2013) Impact of Social Surrounding and sale promotional tools on Customer Purchase Intentions, International Journal of Research in Commerce and Management, 4(3), 156-161

Rizwan, M., Bilal, M., Ashraf, I., Anwar, A., Asif, R. M. \& Arshad, T. (2013) Impact of promotional tools towards product trail in Pakistani consumers: the case of low involvement products. Journal of Basic and Applied Scientific Research, 3(12), 18-25

Rust, R. \&Zahorik, A. (1993). Customer satisfaction, customer retention and market share. Journal of Retailing, 69 (2): 193-215.

Selnes, F. (1993).An examination of the effect of product performance on brand reputation, satisfaction and loyalty. European Journal of Marketing, 27(9), 19-35.

Shavitt, S., Swan, S. Lowrey, T.M. and Wanke, M. (1994) "The interaction of endorser attractiveness and involvement in persuasion depends on the goal that guides message processing", Journal of Consumer Psychology, Vol. 3, No. 2, pp. 137-62. 


\section{Macrothink}

Shira S, Ramu (2003), Marketing. 1st Edition, Delhi: A. H Wheeler and C, Lid-

Sit, J., Merrilees, B. and Birch, D. (2003), "Entertainment-seeking shopping centre patrons: the missing segments", International Journal of Retail \& Distribution Management, Vol. 31 No. 2, pp. 80-94.

Sinha, I. and Smith, M.F. (2000), “Consumers' perceptions of promotional framing of price”, Psychology \& Marketing, Vol. 17 No. 3, pp. 257-75.

Sinha, I., Chandran, R. and Srinivasan, S. (1999), "Consumer evaluations of price and promotionalrestrictions - a public policy perspective", Journal of Public Policy \& Marketing, Vol. 18No. 1, pp. 37-51.

Taylor, S.E. (1998), “The social being in social psychology”, in Gilbert, D.T., Fiske, S.T. and Lindzey, G. (Eds), The Handbook of Social Psychology, McGraw-Hill, Boston, MA, pp. 58-95.

Tellis, G. J. (1988). Advertising exposure, loyalty, and brand purchase: A two-staged model of choice. Journal of Marketing Research, 25(2), 134-144. 